\title{
42. RIFTING AND EARLY DRIFTING: MESOZOIC CENTRAL ATLANTIC AND LIGURIAN TETHYS 1
}

\author{
Marcel Lemoine, Institut Dolomieu, 38031 Grenoble Cedex, France
}

\begin{abstract}
The Leg 76 discovery of Callovian sediments lying above the oldest Atlantic oceanic crust allows us to more closely compare the Central Atlantic with the Mesozoic Ligurian Tethys. As a matter of fact, during the Late Jurassic and Early Cretaceous, both the young Central Atlantic Ocean and the Ligurian Tethys were segments of the Mesozoic Tethys Ocean lying between Laurasia and Gondwana and linked by the Gibraltar-Maghreb-Sicilia transform zone. If we assume that the Apulian-Adriatic continental bloc (or Adria) was then a northern promontory of Africa, then the predrift and early drift evolutions of both these oceanic segments must have been roughly the same: their kinematic evolution was governed by the east-west left-lateral motion of Gondwana (including Africa and Adria) relative to Laurasia (including North America, Iberia, and Europe), at least before the middle Cretaceous $(\simeq 100 \mathrm{Ma})$. By the middle Cretaceous, opening of the North Atlantic Ocean led to a drastic change of the relative motions between Africa-Adria and Europe-Iberia. From this time on, closure of the Ligurian segment of the Tethys began, whereas the Central Atlantic went on spreading.

In fact, field data from the Alps, Corsica, and the Apennines show evidence of a Triassic-Jurassic-Early Cretaceous paleotectonic evolution rather comparable with that of the Central Atlantic. Rifting may have been started during the Triassic (at least the late Triassic) but reached its climax in the Liassic. On the basis of stratigraphic data, drifting appears to have begun in the Middle Jurassic.

The main discrepancies concern (1) the definition of rifting and the time of its beginning, and (2) the time of appearance of the oldest oceanic crust (late Liassic or late Middle Jurassic?). These discrepancies mainly originate from the scarcity of reliable data, as well as from the difficulty of comparing oceanic with alpine data. They may also arise from a certain incompatibility between the complexity of natural facts and the simplicity of man-made models, and, in addition, probably from some real differences in the early evolutions of both oceanic segments.
\end{abstract}

\section{INTRODUCTION}

Mesozoic oceans had many fates: some (e.g., the Atlantic Ocean), are still expanding, whereas the major part of the Mesozoic Tethys disappeared, with only relics of oceanic and marginal continental basements and sediments being now included in Alpine folded belts.

Accordingly, when reconstructing the geological evolution of both oceans, the nature, quality, and amount of available information are quite variable. Therefore, the ways of reasoning as well as the degree of reliability of reconstructions and models of both oceans are hardly comparable. For example, the drifting history of the Atlantic Ocean can be deduced from its magnetic-anomaly pattern, whereas comparable anomalies in the Tethys have been completely disrupted and even rubbed out by later events. Also the methods of study are different; sediments are well-preserved in the Atlantic Ocean, but they are known only through scarce, widely dispersed, and extremely expensive drill holes, between which only seismic profiles allow interpolations. On the other hand, Tethyan sediments are diagenized, folded, and even metamorphosed; but the Alpine ranges may exhibit extensive, beautiful outcrops where, equipped with only mountain boots and perhaps a rope, we can observe and repeatedly study basement rocks, sediments, their lateral variations and intervening unconformities, and much more. Thus easy access and size of the outcrops may well balance the disturbing effects of Alpine folding and

${ }^{1}$ Sheridan, R. E., Gradstein, F. M., et al., Init. Repts. DSDP, 76: Washington (U.S. Govt. Printing Office). even metamorphism. Indeed, the increasing knowledge of present-day oceans has improved our understanding of the geological history of vanished oceans and resulting folded belts; likewise, data and models derived from the latter are useful to the understanding of undeformed oceans and of their history.

As will be shown later, the Mesozoic Central Atlantic and the Ligurian Tethys were "twin oceans," which came into existence nearly at the same time and in the same way. The purpose of this paper is to show how facts and models derived from studying one of these oceans may help in understanding the other.

\section{ATLANTIC AND TETHYS}

The folded belts of the Alps, Corsica, and the Apennines (Fig. 1) are derived from a now-disappeared small ocean and from its European and Apulian-Adriatic continental margins. This narrow ocean is named PiemontLigurian or, more simply, Ligurian, which, in fact, is a segment of a much more extensive ocean, namely, the Mesozoic Tethys.

\section{Mesozoic Tethys}

Between Laurasia to the north and Gondwana to the south, an earlier Paleozoic to Triassic ocean existed prior to the development of the Mesozoic Tethys. Following a modern, simple terminology (Laubscher and Bernoulli, 1977; Bernoulli and Lemoine, 1980), this Paleozoic and Triassic ocean is called Paleotethys, to distinguish it from the middle and late Mesozoic Tethys. According to modern global tectonics, the continents (at least those now known) were welded together at the end 


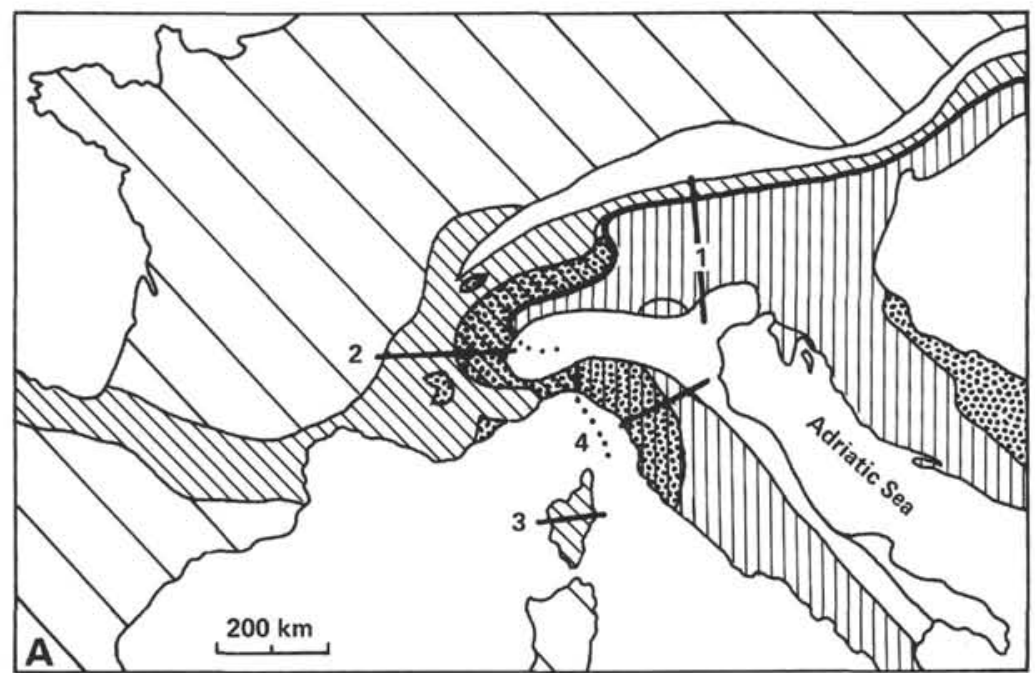

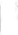
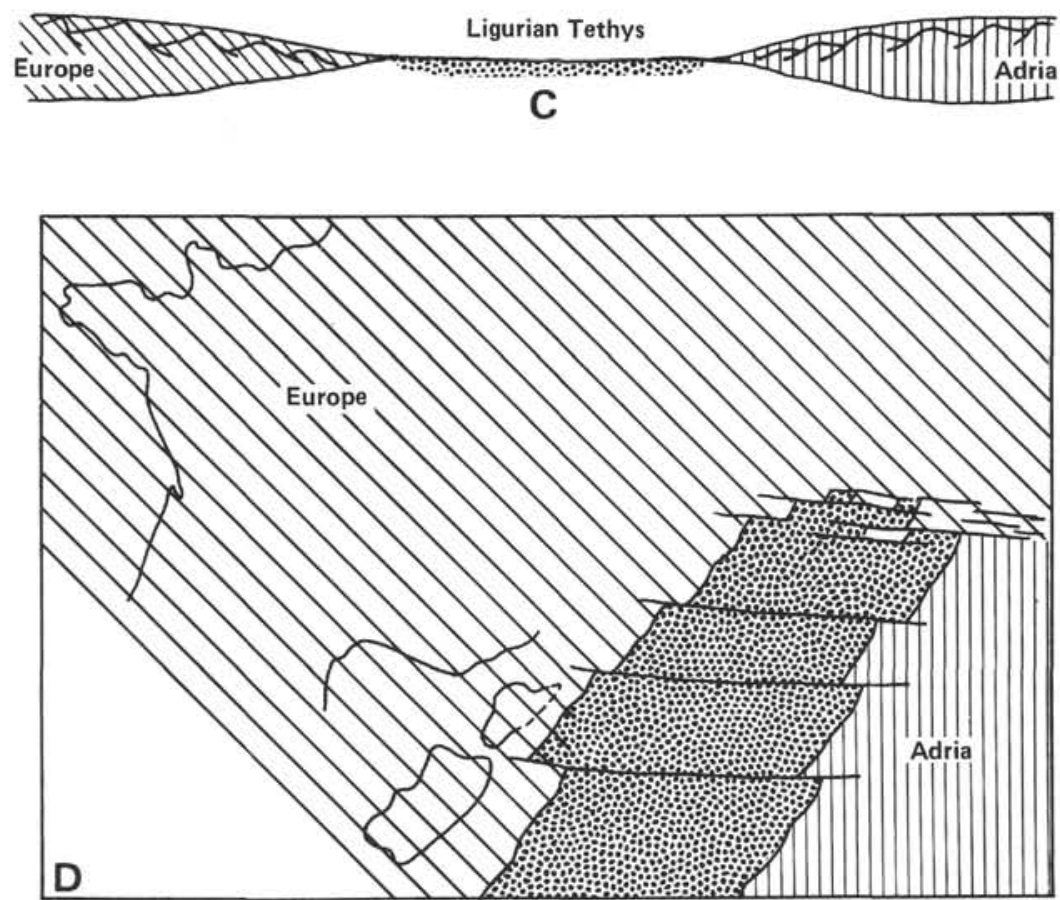

Figure 1. Rough sketch showing oceanic and continental terranes involved in the Alpine folded belts. A. Structural sketch map. B1-4. Highly schematic (no scale) structural sections of the folded belts (location of sections 1, 2, 3, and 4 are shown in Fig. 1A). C. Probable Late Jurassic-Early Cretaceous structure (no scale). D. Hypothetical palinspastic map (Jurassic). (Inclined hatching: Europe and European margin; vertical hatching: Adria margin; dotted areas: oceanic terranes [on the map in Fig. 1A, dots indicate area of the deformed margins where tectonic outliers of ophiolites may occur].) 
of the Paleozoic into a single supercontinent called Pangea, whereas much of the former Paleotethys had already disappeared by subduction or other processes along the so-called "Indosinian suture" (Hsü and Bernoulli, 1978).

During the Mesozoic, the Tethys was a more or less latitudinal oceanic belt lying between the Laurasian and the Gondwanian continents (Figs. 2 and 3 ). To the east of the Apulian-Adriatic continental block (also called Apulia, or Adria), this ocean opened across or along remnants of the Paleotethys, such remnants being very probably associated with continental-crust blocks derived from the northern margin of Gondwana (Jenkyns, 1980; Sengör, 1979; Bernoulli and Lemoine, 1980).

West of Adria, on the contrary, the opening up of the Mesozoic Tethys occurred across Pangea, and with this event the breakup of this megacontinent started.

\section{Mesozoic Breakup of Pangea: Atlantic Break Versus Tethys Break}

The following discussion is restricted to that part of the Tethyan ocean born in the heart of Pangea, i.e., to the Tethys west of Adria.

In fact, the breakup of Pangea initially resulted from the birth and opening up of a network of intraconti-

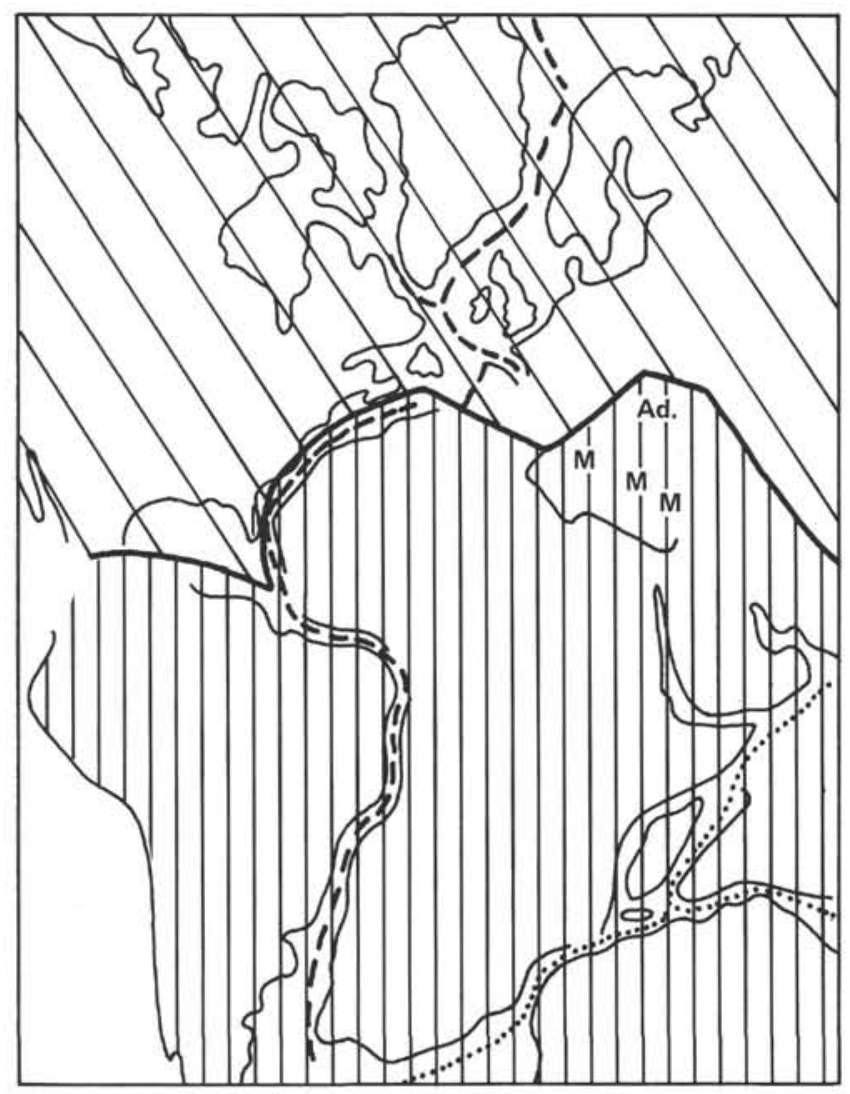

Figure 2. Tethys and Atlantic breaks across Pangea. (Oblique hatching: Laurasia; vertical hatching: Gondwana; heavy lines: full, Tethys break; broken lines: Atlantic break; dotted lines: Indian Ocean breaks. Ad. $=$ Adria , $\mathrm{MMM}=$ possible location of another break in the eastern Mediterranean area. Reassembly of the continents in the late Triassic, after Smith and Briden, 1977.) nental breaks. Leaving aside those that delineated the Indian, Australian, and Antarctic minor continental blocks, let us considerer now those breaks that appeared during the Mesozoic and gave birth to the four major continents, namely, North America, Eurasia, South America, and Africa. As shown on Fig. 2, there are two main, grossly perpendicular, lines of disruption-a latitudinal Tethys break, and a meridian Atlantic break, having in common a Central Atlantic segment. Two different kinematic systems acted successively:

1) The opening of the Tethyan system led to the partition of Pangea into two major continents, Laurasia and Gondwana. This event started during the Early or Middle Jurassic with a left-lateral, latitudinal relative motion of Africa (at that time still welded to South America) with respect to Eurasia (still welded to North America).

2) Rifting and opening of the Atlantic system occurred with a northward progradation: successive openings of the South Atlantic in the Early Cretaceous, of the North Atlantic in the Late Cretaceous, and of the Norwegian sea in the Tertiary. This process led to the progressive individualization of the four major continents.

As we shall see further on, both mechanisms exerted an influence on the fate of the Ligurian Tethys and consequently on the structural history of the Alps.

\section{Central Atlantic and Ligurian Tethys}

As already discussed, the Central Atlantic started its evolution as a mere segment of the Tethyan system and became part of the Atlantic system in the middle Cretaceous. As a matter of fact the northward progradation of the opening of the Atlantic Ocean reached the North Atlantic sector in the middle Cretaceous (around 95 or $100 \mathrm{Ma}$ ), an event that drastically changed relative motions along the Africa-Europe (-Iberia) boundary. With this event, the closure of the Ligurian Tethys began, whereas spreading in the Atlantic continued.

As a consequence of the zigzag path of the Tethys break to the west of Adria, four Tethyan segments can be recognized (Fig. 3): a Caribbean Tethys (more or less a transform zone), an Atlantic Tethys, a GibraltarMaghreb-Sicilia transform zone (left-lateral), and a Ligurian Tethys. In such a model, which seems to apply only to the Late Jurassic-Early Cretaceous, both the Central Atlantic and the Ligurian Tethys are commonly represented with comparable shapes (e.g., Laubscher and Bernoulli, 1977; Bernoulli and Lemoine, 1980). Moreover, assuming the working hypothesis that Adria was promontory of Africa, these oceanic segments appear to have been bounded by the same major continental blocks; one may therefore expect similar evolutions of both oceans, at least preceding $100 \mathrm{Ma}$.

\section{MESOZOIC EVOLUTION OF THE LIGURIAN TETHYS: A SUMMARY}

The paleotectonic evolution of a now-disappeared ocean can be reconstructed in different ways, namely, (1) by use of geological field data from the corresponding folded belts (here, the Alps, Corsica, and the Apen- 


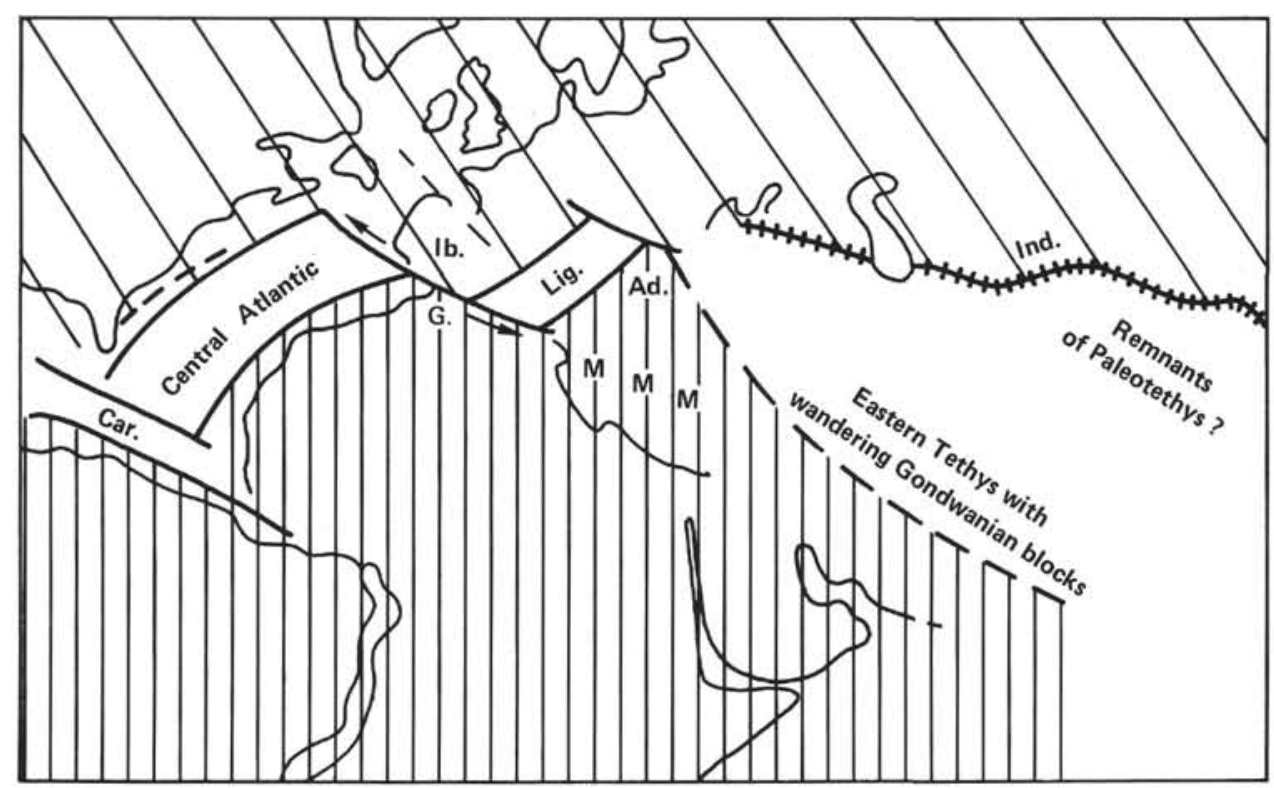

Figure 3. Simplified sketch of the Mesozoic Tethys during the Late Jurassic (Tithonian). (Oblique hatching: Laurasia; vertical hatching: Gondwana; Ib. = Iberia; Ad. = Adria; Car. = Caribbean; G. = Gibraltar-Maghreb-Sicilia transform zone; Lig. = Ligurian Tethys; $\mathrm{MMM}=$ possible eastern Mediterranean branch of the Tethys ("Mesogea" of Biju-Duval et al., 1977).

nines), which can generate environmental and paleotectonic reconstructions, and (2) by global tectonic reconstruction of the relative locations and motions of the surrounding continents. Of course, both approaches complement each other and must therefore be considered.

\section{Stratigraphic-Sedimentary Data: Evidence for Rifting and Drifting}

When considering the Mesozoic sedimentary series in the Alps, in Corsica, and in the Apennines, two main sequences can be distinguished.

(1) The continental margin sedimentary series unconformably lie above a Variscan or older basement; they exhibit as a first approximation a relatively simple evolution from shallow-water marine platform carbonate deposition (mainly Triassic) up to more or less wide-spread hemipelagic sedimentation. This hemipelagic sedimentation began at some places in the late Liassic, elsewhere in the Middle Jurassic, and prevailed, with the exception of some restricted areas, from the earliest Late Jurassic onward. The general (Liassic) passage from shallow-water to pelagic sedimentation corresponds to a phase of sedimentary block faulting leading to differentiation among subsiding basins with pelagic-hemipelagic sedimentation and shallow-water shoals or even emerged areas.

(2) The oceanic sedimentary series, that is, those laid down over the oceanic seafloor (ophiolites), are of pelagic character, and began to be deposited during the earliest Late Jurassic (Oxfordian) (Zia, 1955; de Wever and Caby, 1981), even possibly during the latest Middle Jurassic (Callovian).

Consequently, the first appearance of a true oceanic (i.e., ophiolitic) crust in the Ligurian domain seems to have occurred approximately in the Middle Jurassic (Bathonian or Callovian?). This age is consistent with that of maximum extension of pelagic sedimentation upon both continental margins; however, the collapse of these margins did not occur strictly simultaneously on both sides of the Ligurian Ocean.

Late Cretaceous sediments of both types of series bear the mark of a different tectonic regime (e.g., molassic "Gosau beds" in the eastern Alps; flysch deposits in much of the paleogeographic domains of the Alps and of the Apennines). These facts are consistent with field data (e.g., Upper Cretaceous beds lying unconformably upon older, folded, and even thrusted, terranes), which bear evidence of the beginning of compressional folding in some parts of the Alps and the Apennines.

This first approach thus leads to the adoption, for further discussion, of the following evolutionary frame:

0) late Variscan events (e.g., formation of grabens filled with Permo-Carboniferous molassic deposits);

1) Triassic: "prerifting" period, but with some features of rifting (see the discussion that follows);

2) Liassic: "true" rifting, but without preliminary doming (no emersion along the embryonic continental margins);

3) Middle-Late Jurassic: beginning of ocean spreading, subsidence of continental margins; continuation of spreading during at least part of the Early Cretaceous; and

4) Late Cretaceous: closure of the oceanic area.

\section{Global Tectonic Data: Adria as an} African Promontory?

The Jurassic Ligurian Tethys was contained between two continental blocks, namely, (1) Adria, whose connections and kinematic relations with Africa are dis- 
cussed later, and (2) Europe, which at that time was welded to Iberia (Cretaceous separation) and to Corsica-Sardinia (Tertiary separation).

The magnetic anomalies in the Atlantic Ocean enable us to reconstruct the motions of Africa relative to Europe (Fig. 4). However, reconstruction of the Ligurian Tethys also depends on possible motions of Adria relative to Africa: only if Adria was part of Africa during its Mesozoic history, can the kinematic evolution of the Ligurian Ocean be deciphered.

In fact, recent critical reviews of paleomagnetic data concerning Adria (Channel et al., 1979; d'Argenio et al., 1980; Lowrie, 1980) conclude that there has been no significant rotation-or, at most, little rotation-of Adria relative to Africa. As will be seen later, field evidence appears to be consistent with this conclusion. Beside a certain amount of displacement, which may have occurred during the Late Cretaceous or the Tertiary compressional events, Adria may have been, at least during the Jurassic, a promontory of Africa (Fig. 5). But this is, of course, nothing but a hypothesis.

If we adopt this hypothesis, the motion of AfricaAdria relative to Europe implies Late Jurassic-Early Cretaceous opening and spreading of the Ligurian Ocean, a conclusion that is consistent with the earlier mentioned stratigraphic, sedimentological, and paleotectonic data.

Nevertheless, at this state of our reasoning, both shape and width of the Ligurian Ocean remain unknown; they depend on the shape of the western flank of Adria, that is, on the path of the initial break. As a matter of fact, this flank has been deformed or obliterated by subsequent tectonic events, namely, by the Alpine collisional deformations as well as by the still-later formation of the young Mediterranean back-arc basins (e.g., the Tyrrhenian Basin). To solve this problem, other lines of evidence originating from field research both in the Alps and in the Apennines must be taken into consideration.

\section{Liassic Rift Structures, Their Directions in the Alps and the Apennines, and Their Relations to the Ligurian Rhombochasm}

Spectacular examples of Liassic synsedimentary block faulting have been described both along the European margin (western Alps and their Cévennes foreland: de Graciansky et al., 1979, 1980; Lemoine et al., 1981; Lemoine, in press) and in the Adria margin (southern Alps: Bernoulli et al., 1979; d'Argenio et al., 1980; Castellarin et al., 1978). After the Triassic events (see the following discussion), the Liassic rifting gave birth to a system of synsedimentary horsts and grabens, among which tilted blocks bounded by inclined (listric?) normal faults are rather frequent (e.g., see Gaetani, 1975; Lemoine et al., 1981). Most of these Liassic faults reworked into thrust faults or strike-slip faults during the Tertiary orogeny; at certain places, however, they remained rather well-preserved (southern Alps; foreland and external zone of the western Alps: Fig. 6). In such places, these Liassic faults can be either actually observed in the field or at least reconstructed from field evidence; their directions can sometimes be mapped (Fig. 6).

Examples such as the Celtic-North Biscay margin (Montadert et al., 1979) or the Gulf of Suez (Garfunkel and Bartov, 1977) suggest that the mean trend or the rifting-originated structures (elongation of main horsts and grabens, listric faults that bound tilted blocks) may be more or less parallel to the intracontinental break, that is, to the ocean continent boundary.

If we accept this postulate, some consequences can be deduced regarding both the motions of Adria and the shape of the Ligurian Tethys. As a matter of fact, both in the western Alps (European margin) and in the southern Alps (Adria margin), the preserved Liassic rift directions follow almost the same northeast to north-northeast trend. As a consequence, (1) a significant (more

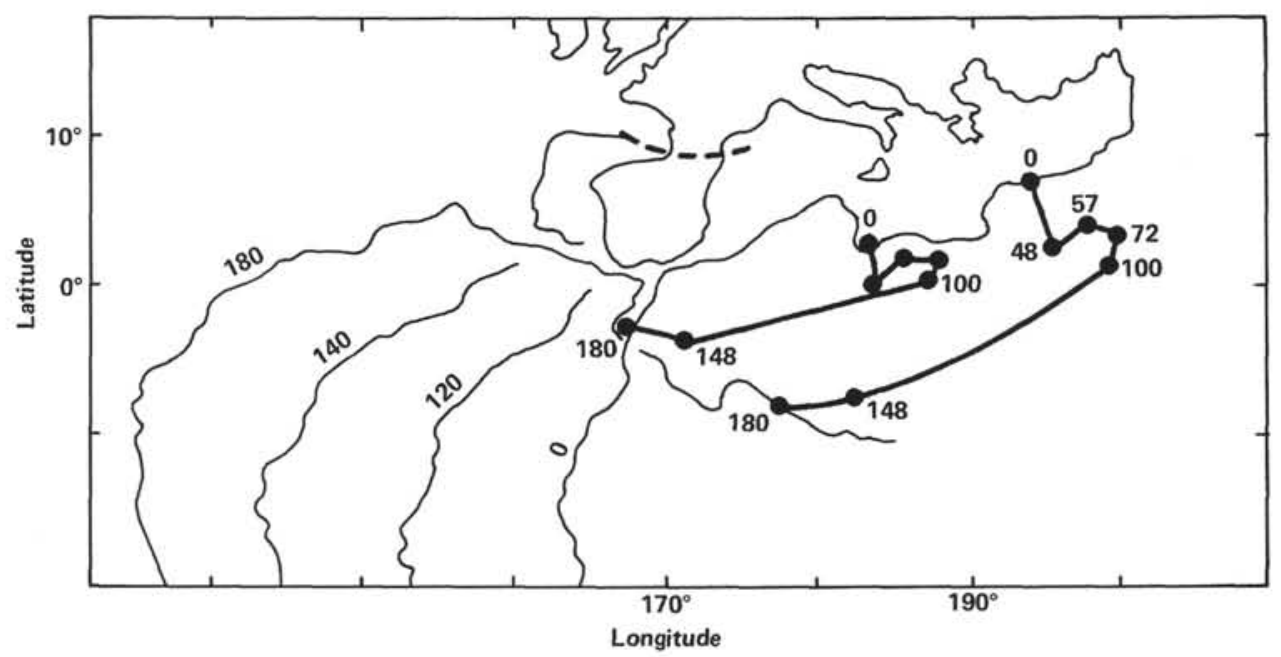

Figure 4. Motions of Africa relative to Europe (after Biju-Duval et al., 1977). (These relative motions may be divided into two stages: [1] Tethyan kinematics between 180 [160?] and $100 \mathrm{Ma}$ [opening of Central Atlantic and Ligurian Tethys]; and [2] combination of Tethyan and Atlantic kinematics from $100 \mathrm{Ma}$ onward [Tethys closure, continental collision]. Note that an estimate for the beginning of motion at $180 \mathrm{Ma}$ may be somewhat too early, as suggested in this paper.) 


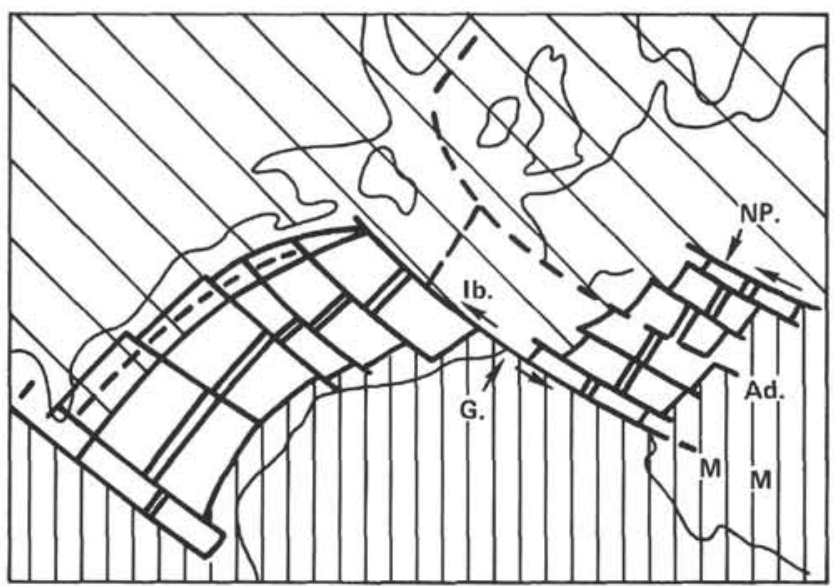

Figure 5. Late Jurassic Central Atlantic and Ligurian Tethys: a tentative model. $(\mathrm{Ib} .=$ Iberia; Ad. = Adria; G. = Gibraltar-Alboran transform zone; NP. $=$ North Penninic transform zone; $M=$ possible oceanic-crust area in the eastern Mediterranean ["Mesogea" of Biju-Duval et al., 1977]. Relative location of continents in the Late Jurassic [Tithonian], after Smith and Briden [1977]. Transform faults shown in the Central Atlantic are believed to be the ancestors of present-day transform faults [Oceanographer, Hayes, Atlantis, Kane, Barracuda, Vema]. But those that are drawn in the Ligurian Tethys are hypothetical both in location and magnitude of offset; they are here shown for the sole purpose of suggesting the very likely presence of numerous strike-slip faults in this area.) thian 20-30 ${ }^{\circ}$ ) rotation of Adria relative to Europe seems unlikely; (2) the initial Ligurian-Tethys break was very likely orientated northeast to north-northeast with respect to Europe; and (3) the "Ligurian rhombochasm model" can be adopted as a first approximation.

Such a highly simplified rhomb-shaped oceanic area (Figs. 3 and 5) appears to have been bounded in the Jurassic (1) by two passive margins, the Adriatic one to the southeast and the European one to the northwest, and (2) by two transform margins, the Gibraltar strike-slip zone to the south and the hypothetical North-Penninic strike-slip zone to the north (e.g., see Kelts, 1981). But this scheme is oversimplified, and needs to be complicated by introducing transform faults cutting both passive margins as well as the ocean-crust area (Bourbon et al., 1977; Lemoine, 1980). Let us point out, for instance, that the first Tethyan "oceanic" sediments were often laid down directly upon a serpentinic or gabbroic basement, or upon ophiolitic breccias (Fig. 7) similar to those encountered along recent oceanic fracture zones.

\section{CENTRAL ATLANTIC DATA}

Assuming, as a working hypothesis, that at least in the Jurassic Adria was a promontory of Africa, we may suggest that rifting and early drifting stages were more or less analogous and coeval in both the Central Atlantic and the Ligurian Tethys. A detailed comparison, how-

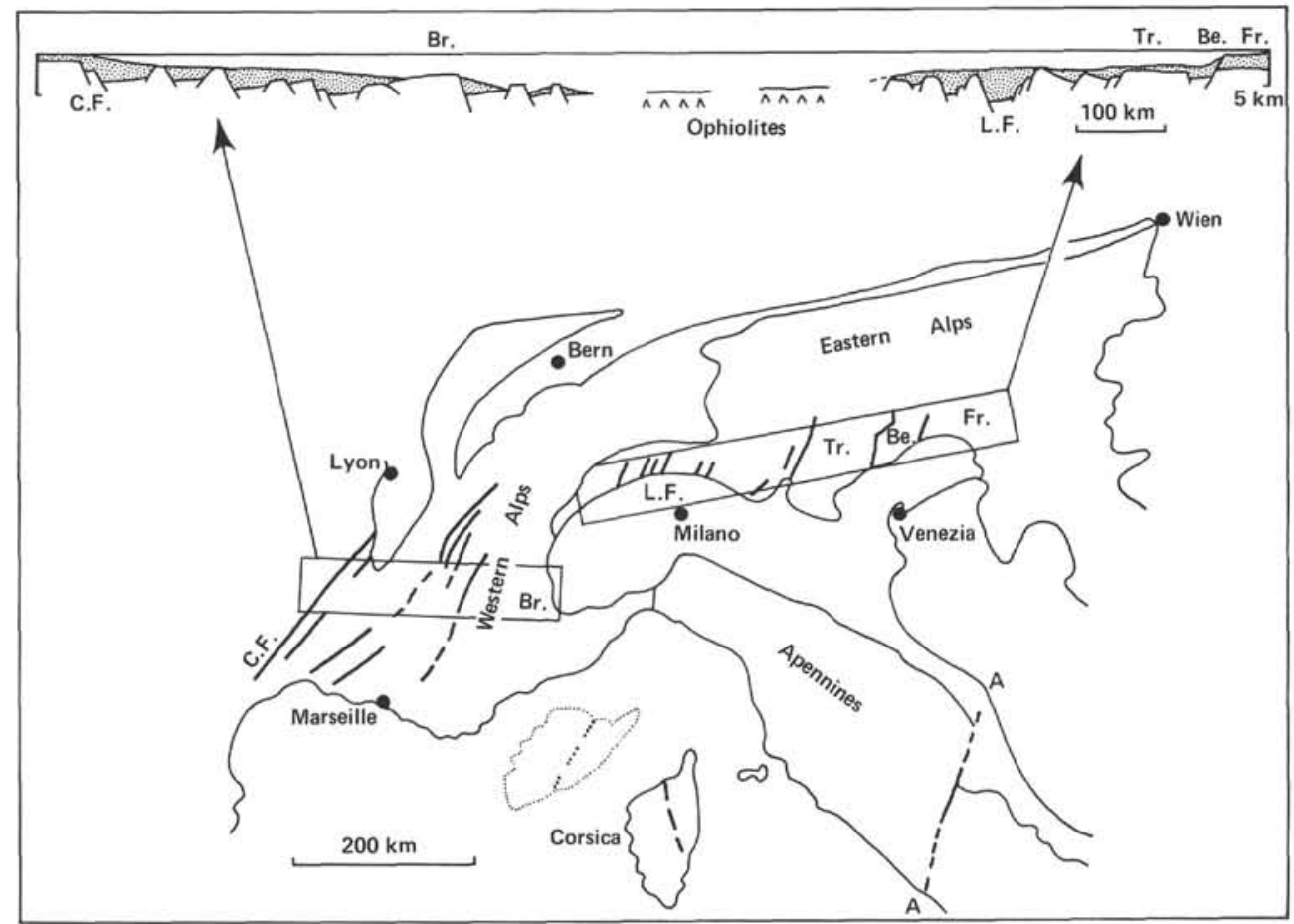

Figure 6. Mesozoic structural directions related to rifting in the western Alps (European continental margin) and in the southern Alps (Adria continental margin). (Heavy lines indicate known Liassic synsedimentary faults, which mainly bounded tilted blocks; C.F. = Cevennes fault; L.F. = Lugano fault; mainly after Gaetani [1975], Winterer and Bosellini [1981], Arnaud et al. [1976], and Lemoine et al. [1981]. Br. = Brianconnais domain; $\mathrm{Tr} .=$ Trento high; $\mathrm{Be} .=$ Belluno trough; Fr. = Friuli platform. The upper section shows a reconstruction of Late Jurassic margins [dotted areas = Jurassic, mainly synrift, sediments].) 


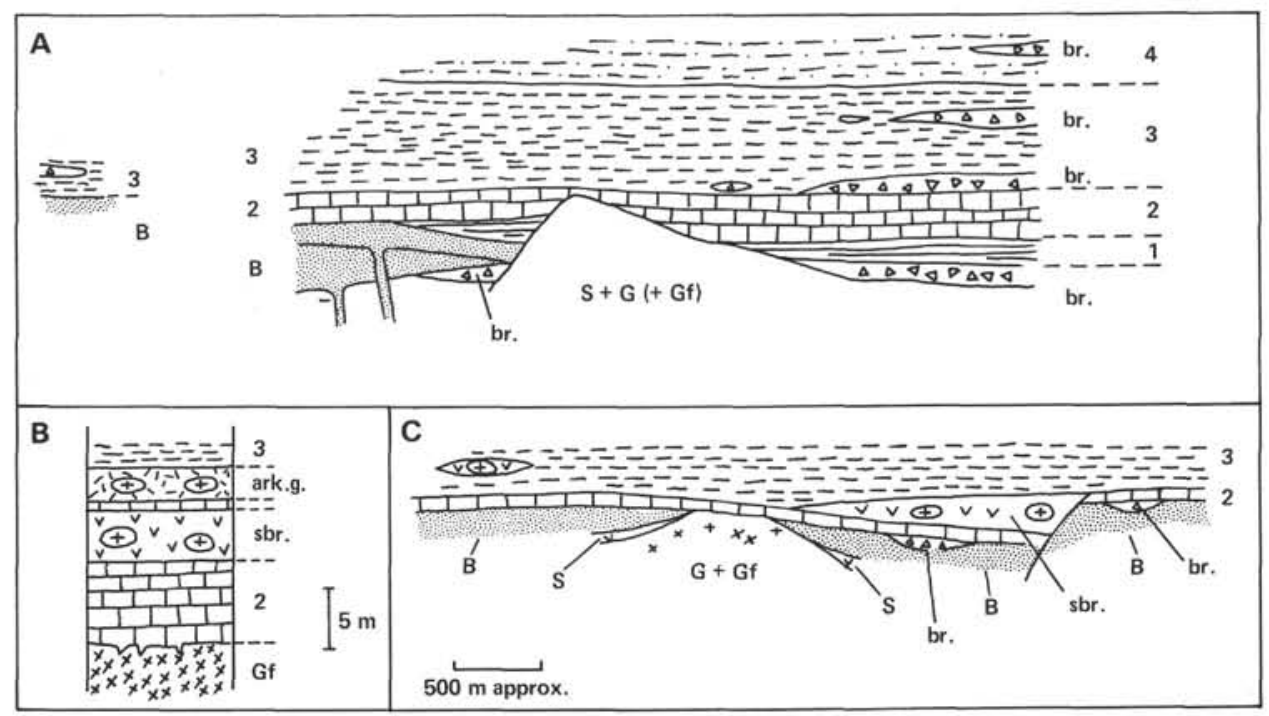

Figure 7. Relations between oceanic basement and overlying sediments in the Ligurian Tethys. A. Schematic diagram using data from the northern Apennines, Corsica, and the western Alps. (Ophiolitic rocks: $\mathrm{S}=$ serpentinites; $\mathrm{G}=$ gabbros; $\mathrm{Gf}=$ foliated gabbros. Basalts (mainly pillow lavas and related breccias) = B; br. = ophiolitic sedimentary breccias (including most ophicalcites) and ophiolitic olistoliths. Pelagic sedimentary series: 1 = radiolarian cherts [Oxfordian-Kimmeridgian, $0-30 \mathrm{~m}$ ]; $2=\mathrm{Cal}$ pionella limestones [Tithonian-Berriasian, $0-50 \mathrm{~m}$ ]; $3=$ limestones and shales, or calc-schists [Early Cretaceous, seveal hundred meters]; $4=$ sandstones and shales [Late Cretaceous, several hundred meters]. B and C. Two examples chosen from the western Alps. Note that other, numerous examples would show the pelagic sediments resting directly upon a serpentinite bottom capped by ophicalcites. B. Pelvas d'Abries section (after Lagabrielle et al., 1982). (The Upper Jurassic limestones were directly deposited, with local unconformity, upon already foliated gabbros. sbr. = more or less brecciated serpentinites (olistoliths and/or sedimentary breccias) containing huge rounded blocks of gabbro; ark.g. $=$ arkose made up of gabbroic debris.) C. Rocca Bianca-Lac Blanchet series (after Lagabrielle et al., 1982). (This section results from unfolding the present-day folded structure. No vertical scale. Note that the breccias and olistoliths [sbr.] in the half-graben were probably 20 to $30 \mathrm{~m}$ thick.)

ever, is still difficult, as data concerning the Triassic and Jurassic sediments of the continental margins and of the oceanic area of the Atlantic are rather scarce.

In the North Atlantic-Biscay system, the occurrence of "starved margins" (at least in the Iberian and North Biscay sectors) allows both synrift sediments and structures to be drilled and reconstructed. In contrast, the Central Atlantic continental margin sediments are much thicker: there, the deepest sediments and structures are in most cases beyond the reach of drilling, and interpretation of seismic profiles is difficult.

On both margins of the Central Atlantic, only a limited number of drill holes (e.g., see Manspeizer et al., 1978; Grow and Sheridan, 1980) provide some information on Triassic and Jurassic beds; other information comes from the neighboring land areas (Manspeizer et al., 1978; Lancelot and Winterer, 1980). All this information suggests that rifting occurred during the Triassic (at least the Late Triassic) and Liassic (at least the early Liassic).

In the deep ocean, the Jurassic crust has been reached in very few DSDP drill holes $(100,105,534)$; it is only Leg 76 results (this volume) that have led to the discovery of the oldest, or nearly oldest, Central Atlantic oceanic crust and, accordingly, to the reinterpretation of the ages of the Jurassic magnetic anomalies. From these results, one may wonder whether a $180-\mathrm{m}$.y. (late Liassic) birth of the Central Atlantic oceanic crust can be ruled out, except perhaps for the inferred oldest crust concealed below thick sediments of the North American East Coast rise and slope.

From this information, and especially from stratigraphic data, it appears rather likely that in the Central Atlantic drifting started 150 or $160 \mathrm{Ma}$ (Bathonian-Callovian), subsequently to rifting during the late Triassic and Liassic.

\section{COMPARISON AND DISCUSSION}

The time scale of the early evolution of the Ligurian Tethys described earlier can now be compared with that of the Central Atlantic (Table 1). It must be remembered that some of the data used to establish this Tethyan time scale derive from the stratigraphic paleotectonic study of the Alps, of Corsica, and of the Apennines;

Table 1. Atlantic versus Tethyan time table.

\begin{tabular}{|c|c|c|c|c|}
\hline \multirow{2}{*}{$\begin{array}{l}\text { Age } \\
\text { (m.y.) }\end{array}$} & \multirow[b]{2}{*}{ Age } & \multicolumn{2}{|c|}{ Atlantic } & \multirow[b]{2}{*}{ Ligurian Tethys } \\
\hline & & Central & North + Biscay & \\
\hline 65 & Tertiary & Drifting & Drifting & Collision \\
\hline \multirow[t]{2}{*}{100} & Late Cretaceous & Drifting & Drifting & Closure \\
\hline & Early Cretaceous & Drifting & Drifting and rifting & End of drifting \\
\hline $\begin{array}{l}135 \\
150\end{array}$ & Malm & Drifting & Rifting and/or prerift & Drifting \\
\hline 175 & Dogger & $\begin{array}{l}\text { Early drifting? } \\
\text { End of rifting? }\end{array}$ & & $\begin{array}{l}\text { Early drifting? } \\
\text { End of rifting }\end{array}$ \\
\hline \multirow[t]{2}{*}{190} & Liassic & Rifting & & Rifting \\
\hline & Triassic & Rifting and/or prerift & & Rifting and/or prerift \\
\hline
\end{tabular}


others are deduced from Central Atlantic data, particularly from the magnetic anomalies that allow kinematics of the surrounding continental blocks to be reconstructed. These latter data were used mainly to support the former ones derived from stratigraphic and tectonic research in the folded belts.

In this table, time limits, as well as a definition of what is rifting, appear to be somewhat fuzzy. In fact, for a simple, clear-cut model of margin evolution, the onset of the rifting period should be known as well as its transition into the drifting period. Definition of these critical moments is, however, extremely difficult. Even should sufficient geological data be available, natural events are more complicated than usually recognized, and have a perverse tendency to eschew rigid man-made frames.

\section{Triassic-Liassic Rifting Versus Liassic Rifting Alone}

Definition of the nature of rifting and of the time of its onset varies widely from one area to the other and also from author to author.

In the Central Atlantic, available data generally come from the surrounding land areas and from some neighboring offshore basins, for example, from the eastern part of North America (south of Newfoundland) and from the western part of Africa (north of Cape Verde). There, late Triassic and Early Jurassic rocks obviously bear witness to distensional events: synsedimentary infilling of grabens, emplacement of both volcanic flows and hypovolcanic dykes and sills (May, 1971; Van Houten, 1977; Manspeizer et al., 1978). Similar events also occurred in the middle-late Liassic (e.g., in the Moroccan High Atlas); volcanic activity, however, faded out. These events may be seen in the frame of a phase of Triassic-Liassic rifting preceding the opening up of the Central Atlantic (e.g., see Roberts and Caston, 1975; Van Houten, 1977; Lancelot and Winterer, 1980; Grow and Sheridan, 1980).

Around the Ligurian Tethys, Triassic and Jurassic deposits in the Alps and in the Apennines, and their possible relation to rifting, must be interpreted somewhat differently. In fact, what is first noticed is a sharp contrast between Triassic and Liassic sedimentary environments: platform carbonates (mainly marine) prevailed during the Triassic, whereas the dawn of the Liassic marks the disintegration of the former carbonate platform, giving birth to a system of marine basins and of marine or emergent shoals as a result of synsedimentary block faulting (Bernoulli and Jenkyns, 1974). This Liassic faulting often resulted in synsedimentary tilted blocks bounded by probably listric normal faults (Fig. 6) (see de Graciansky et al., 1979; Bally et al., 1981). Both tectonic style and sedimentary features of the Liassic Tethyan rifting appear to fit models of passive continental margins derived from the study of present-day oceans.

An especially close comparison has been worked out (de Graciansky et al., 1979) between the European Tethyan margin (Liassic rifting) and the starved margins of the eastern side of the North Atlantic (Iberian and North Biscay passive margins: Early Cretaceous rifting). In the latter margins, a distinction has been pro- posed between synrift and prerift formations (Montadert et al., 1979), which boils down to taking the acoustic basement as a boundary; this boundary corresponds to events related to the collapsing or tilting of the nowobservable crustal blocks from earlier, in fact, poorly known, events. But the question arises whether these "earlier" events can rightly be termed "prerift." In fact, as an example, both the Triassic and the Jurassic rocks of Portugal provide evidence for distensional events during this so-called "prerift" period.

Returning to the Ligurian sector, it appears obvious that the Triassic epoch (Fig. 8), even if dominated by platform carbonate deposition, was nevertheless a period also dominated by distensional tectonics. This factor is evidenced by (1) important variations in subsidence rates of the platform carbonate series, (2) middle Triassic or late Triassic development of small episodic hemipelagic basins in the heart of, or between, these platforms, and (3) local volcanic activity in the middle Triassic (southern $\mathrm{Alps}^{2}$ ) or in the late Triassic (western Alps). Taken together, these facts have led certain authors to speak of a "middle Triassic aborted rifting", (Bechstädt et al., 1978), whereas others invoke "Triassic seaways" which did not coincide with the Liassic Tethys break (Scandone, 1975; see also Argyriadis et al., 1980; Winterer and Bosellini, 1981).

Whatever the case, it must be emphasized that neither Triassic nor Liassic doming occurred before the opening of the Ligurian Tethys. On the contrary, the Liassic rifting, prior to any appearance of oceanic crust, initiated oceanic-water circulation as a result of block faulting coupled with a certain amount of subsidence.

Thus it appears that when regarding the onset of rifting, the Ligurian model does not exactly fit with the Central Atlantic events. This may result from an actual difference in evolution, but also from scarcity of reliable data in both areas.

To conclude, distensional tectonics obviously acted as early as the Triassic over a very broad part of Pangea and lasted up the middle to late Liassic at least; moreover, the onset of actual rifting may have been diachronous. Nevertheless, Tethyan data strongly suggest that a significant geodynamic change took place with the dawn of the Liassic.

\section{Transition from Rifting to Drifting}

In the Central Atlantic and in the Ligurian Tethys, the time of the beginning of drifting, that is, of the first appearance of oceanic crust, must be derived from different lines of evidence that sometimes give contradictory results. Besides indirect, disputable evidence (time of collapse of continental margins, time of beginning of free oceanic-water circulation), direct evidence may be derived both from radiometric dating of the oceanic (ophiolitic) crust, and from paleontological dating of the first sediments deposited upon this crust.

\footnotetext{
2 As the writer sees it, the presence of shoshonitic rocks in middle Triassic volcanites of the southern Alps cannot be taken as a final argument for calc-alkaline magmatism, even less for a Triassic subduction (Castellarin et al., 1979), because shoshonites may also occur associated with continental tholeiitic volcanites linked with the breakup of Pangea (e.g., Tuli shoshonites in South Africa, Cox, 1972).
} 


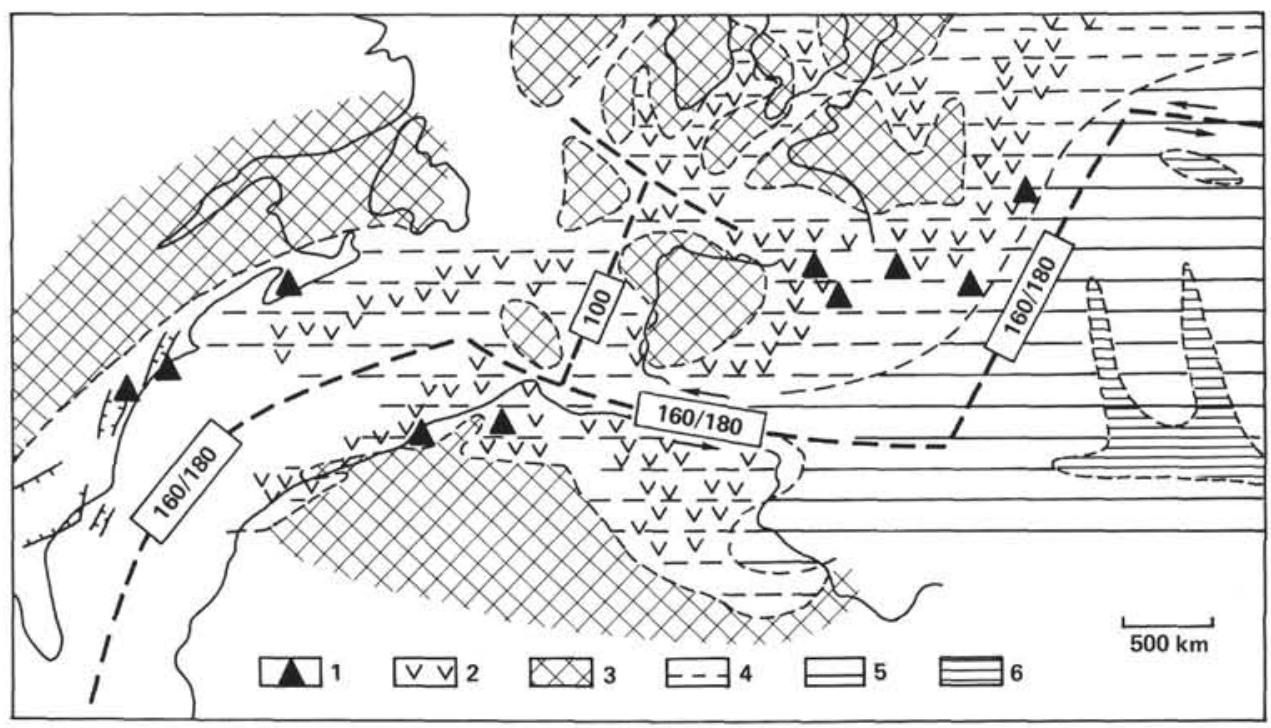

Figure 8. Sketch showing late Triassic paleogeography between North America and Adria (modified from Jansa et al., 1980; Bernoulli and Lemoine, 1980). $(1=$ volcanism; 2 = latest Triassic-earliest Liassic evaporites; 3 =emerged land; 4 = areas periodically invaded by seawater [fluvial, sabkha, lagoonal environments, etc.]; $5=$ carbonate platforms [tidal flats], with local deposition of evaporites in the earliest late Triassic (Carnian); 6 = pelagic seaways [e.g., ammonite-bearing limestones and marls of the so-called Hallstatt facies]. Some major eastern North American grabens are also shown. The heavy broken line shows the path of the future Tethys break [opening around 160 or $180 \mathrm{Ma}$ ) and of the North Atlantic-Bay of Biscay breaks [opening around $100 \mathrm{Ma}$ ]. The light broken line simply indicates the boundaries between $3,4,5$, and 6 . Note that there is apparently no close positional relationship between the wide area over which latest Triassic to earliest Liassic evaporite deposition took place, and the future Tethys break [in the late Liassic? or Middle Jurassic]; nevertheless, when regarding only the northern part of the Central Atlantic Ocean, such a relationship may exist.)

Radiometric ages of ophiolites in the Alps, in Corsica, and in the Apennines are difficult to interpret, because they are dispersed from the Liassic up to the Late Cretaceous. Before any discussion, more data are needed. Nevertheless, at the present stage of our knowledge, dating the oldest Ligurian oceanic crust as late Liassic cannot be definitely ruled out, even if it contradicts stratigraphic data.

Biostratigraphical data show us that the oldest earliest known deposits covering the Central Atlantic oceanic crust are Callovian (Site 534 report, this volume).

In the Ligurian Tethys (Fig. 7), ophiolites are overlain first by undated ophicalcitic breccias, and then by pelagic sediments, which at some places have been dated by means of microfossils: (1) radiolarian cherts, of the late Oxfordian-early Kimmeridgian (de Wever and Caby, 1981); (2) pelagic limestones of the Tithonian-Berriasian (Zia, 1955); and (3) pelagic limestones and shales of the early Cretaceous; the latter may directly overlay ophiolitic pillow lavas, which may suggest either continuation of spreading of oceanic crust up to the Early Cretaceous, or deposition upon a rugged oceanic basement. In fact, paleontological evidence points toward deposition in the Oxfordian (possibly the Callovian, as far as the undated ophiolitic breccias are considered) for the oldest sediments, which suggests that the Ligurian oceanic crust was not older than Callovian or Bathonian. Nevertheless, there is much yet to discover, because Alpine "oceanic" sediments are very often metamor- phosed and strongly folded, and, in any case, practically devoid of fossils. Moreover, a significant part of the Ligurian oceanic crust has been subducted or eroded away.

\section{Collapse of Tethyan Continental Margins}

It is generally observed that a regional subsidence of the continental margins more or less coincides with the beginning of drift, that is, with the earliest appearance of an oceanic bottom (cf., Falvey, 1974).

Again, Alpine data do not fit a simple model. At first glance, an asymmetry appears between both margins: both the end of rifting and the onset of regional subsidence occurred in the Domerian-Toarcian (approx. 180 $\mathrm{Ma}$ ) in the Adria margin, and only later (Bathonian-Callovian, approx. 150-160 Ma) in the European margin. Moreover, a closer examination shows that block faulting did not end at the same time everywhere in a given margin. A clear-cut time limit cannot therefore be established. As stressed by Winterer and Bosellini (1981), "it may be that in close-up view the broad picture of a passive margin seen on seismic records is lost in the welter of local complexities, or perhaps that the broad seismic picture is an oversimplification of reality."

Additionally, in the northern part of the Ligurian Tethys and close to a probable "North-Penninic transform zone," closely-spaced transform faulting may have been responsible for local complications (causing exceptions to the general rule) and possibly also for the pre- 
mature birth of small local pull-apart basins with ophiolitic bottoms, and for the delayed submergence of certain horsts.

\section{CONCLUSION}

If Adria was a mere northern promontory of Africa, at least in Jurassic times, the Central Atlantic and the Ligurian Tethys were kinematically linked, and their tectonic-sedimentary evolutions may therefore be directly compared with each other. As a matter of fact, in most cases such comparison of data yields a fairly good agreement, although discrepancies are noted.

In predrift times, the Central Atlantic and Ligurian areas show some differences in paleotectonic evolution. Tensional tectonic events occurred as early as the Triassic along both segments of the future, Jurassic Tethys break.

In the Ligurian sector, a new element was added to the picture when Liassic rifting began. In this area, there was no uplifting ("doming") before or during rifting; on the contrary, transition from the Triassic "abortedrifting" stage to the Liassic rifting s. str. period led to an increased collapse of the margins-in-being, at least of some grabens, enhancing free oceanic-water circulation. This seems to have permitted the start of a westward "reconquest"' (Aubouin et al., 1977) by open-marine waters, from the eastern Tethys toward the eastern Central Atlantic, as a forerunner of actual drifting. Another feature of Liassic rifting in the Ligurian sector may have been the occurrence of tilted blocks bound by mainly oceanward-inclined normal faults, suggesting stretching of the continental crust.

Based on biostratigraphical data, the transition from rifting to drifting appears to have occurred approximately at the same time both in the Central Atlantic and in the Ligurian Tethys. Site 534 results (this volume) and the discovery of a surprisingly well-preserved radiolarian fauna in highly metamorphosed radiolarian cherts of the western Alps (de Wever and Caby, 1981), indicate a concordant Bathonian or Callovian age for the oceanic opening both in the Central Atlantic and in the Ligurian Tethys. Nevertheless, indirect, preliminary evidence suggests that at some places oceanic crust may have been formed somewhat earlier, both in the western Central Atlantic (close to the North American East Coast), and in minor parts of the Ligurian Tethys. These questions, however, obviously require further research.

\section{ACKNOWLEDGMENTS}

The author is greatly indebted to A. W. Bally, D. Bernoulli, M. Gidon, P. C. de Graciansky, F. Gradstein, and G. Mascle for their critical reading of the first draft and helpful suggestions, which led to considerable improvement of the paper. Thanks are due also to D. Bernoulli and J. Girault who spent much time correcting and improving the language.

\section{REFERENCES}

Argand, E., 1924. La tectonique de l'Asie. Proc. Int. Congr. Geol., 13:171-372.

d'Argenio, B., Horvath, F., and Channell, J. E. T., 1980. Paleotectonic evolution of Adria, the African promontory. Int. Geol. Congr. 26th, Paris 1980, Coll. C5:331-351.

Argyriadis, I., de Graciansky, P. C., Marcoux, J., and Ricou, L. E., 1980. The opening of the Mesozoic Tethys between Eurasia and
Arabia-Africa. Int. Geol. Congr. 26th, Paris 1980, Coll. C5: 199-214.

Arnaud, H., Barfety, J. C., Gidon, M., and Palris, J. L., 1978. A propos du rhegmatiseddes zones externes alpines au Sud de Grenoble. C. R. Acad. Sci. Paris, Ser. D, 286:1335-1338.

Aubouin J., Blanchet, R., Stefan, J. F., and Tardy, M., 1977. Téthys (Mésogée) et Atlantique: données de la geologie. C.R. Acad. Sci. Paris, Ser. D, 285:1025-1028.

Bally, A. W., Bernoulli, D., Davis, G. A., and Montadert, L., 1981. Listric normal faults. Geology of Continental Margins, Oceanologica Acta, Int. Geol. Congr. 26th, Coll. C3:87-101.

Bechstädt, T., Brandner, R., Mostler, H., and Schmidt, K., 1978. Aborted rifting in the Triassic of the Eastern and Southern Alps. Neues Jahrb. Geol. Palaeontol. Abh., 156(2):157-178.

Bernoulli, D., 1964. Zur Geologie des Monte Generoso (Lombardische Alpen). Beitr. Geol. Karte Schweiz, N.F., 118. ,1972. North Atlantic and Mediterranean Mesozoic facies: a comparison. In Hollister, C. D., Ewing, J. I., et al., Init. Repts. DSDP, 11: Washington (U.S. Govt. Printing Office), 801-871. 1980. Southern Alps of Ticino. In Trumpy, R. (Ed.), An Outline of the Geology of Switzerland. Int. Geol. Congr. 26th, Paris 1980, Guide Book Excursions in Switzerland.

Bernoulli, D., and Jenkyns, H. C., 1974. Alpine, Mediterrannean, and Central Atlantic Mesozoic facies in relation to the early evolution of the Tethys. In Dott, R., and Shaver, R. (Eds.), Modern and Ancient Geosynclinal Sedimentation. Soc. Econ. Paleontol. Mineral, Spec. Publ., 19:129-160.

Bernoulli, D., Kälin, O., and Pattaca, E., 1979. A sunken continental margin of the Mesozoic Tethys: the Northern and Central Apennines. Assoc. Sedimentol. Fr. Publ. Spec., 1:197-210.

Bernoulli, D., and Lemoine, M., 1980. Birth and early evolution of the Tethys: the overall situation. Int. Geol. Congress 26th, Paris 1980. Coll. C5:169-179.

Biju-Duval, B., Dercourt, J., and LePichon, X., 1977. From the Tethys ocean to the Mediterranean seas: a plate tectonic model of the evolution of the Western Alpine System. In Biju-Duval, B., and Montadert, L. (Eds.), Int. Symposium on the Structural History of the Mediterranean Basins (Split, 1976): Paris (Technip.), pp. 143-164.

Bosellini, A., and Winterer, E. L., 1975. Pelagic limestone and radiolarite of the Tethyan Mesozoic: a genetic model. Geology, 3: 279-282.

Bourbon, M., Caron, J. M., de Graciansky, P., Lemoine, M., Mégard-Galli, J., and Mercier, D., 1977. Mesozoic evolution of the Western Alps: birth and development of part of the oceanic Tethys and of its European continental margin. In Biju-Duval, B., and Montadert, L. (Eds.), Int. Symposium on the Structural History of the Mediterranean Basins (Split, 1976): Paris (Technip.), pp. 143-164.

Castellarin, A., 1972. Evoluzione paleotettonica sinsedimentaria del limite tra "Piattaforma Veneta" e "Bacino Lombardo" a Nord di Riva di Garda. G. Geol. Bologna, 2a(38):11-212.

Castellarin, A., Colacicchi, R., and Praturlon, A., 1978. Fasi distensive, trascorrenze et Sovrascorrimenti lungo la "linea AnconaAnzio," dal Lias Medio al Pliocene. Geol. Romana, 17:161-189.

Castellerin, A., Lucchini, F., Rossi, P. L., Simboli, G., Bosellini, A., and Sommavilla, E., 1979. Middle Triassic magmatism in Southern Alps II: a geodynamic model. Riv. Ital. Paleontol., 85: 111-1124.

Channell, J. E. T., d'Argenio, B., and Horvath, F., 1979. Adria, the African promontory, in Mesozoic Mediterranean paleogeography. Earth Sci. Rev., 15:213-292.

Channell, J. E. T., and Horvath, F., 1976. The African-Adiratic promontory as a paleogeographical premise for Alpine orogeny and plate movements in the Carpatho-Balkan region. Tectonophysics, 35:71-101.

Cox, K. G., 1972. The Karoo volcanic cycle. J. Geol. Soc. London, 128:311-336.

de Graciansky, P. C., Bourbon, M., Chenet, P. Y., de Charpal, O., and Lemoine, M., 1979. Genèse et évolution comparées de deux marges continentales passives: marge ibérique de l'Océan Atlantique et marge européenne de la Téthys dans les Alpes Occidentales. Bull. Soc. Geol. Fr., 7(21):663-674.

de Graciansky, P. C., and Lemoine, M., 1980. Excursion 27. Paléomarge de la Téthys dans les Alpes occidentales, du Massif Central 
français aux ophiolites liguropiémontaires. Int. Geol. Congr. 26th, Paris, 1980. Guide Book Excursions in France.

Falvey, D. A., 1974. The development of continental margins in platetectonic theory. APEA J., 14:95-106.

Gaetani, M., 1975. Jurassic stratigraphy of the Southern Alps. In Squyres, C. (Ed.), Geology of Italy: Tripoli (The Earth Sciences Society of the Lybian Arab Republic, 1975), pp. 377-402.

Garfunkel, Z., and Bartov, Y., 1977. The tectonics of the Suez rift. Geol. Surv. Israel Bull., 71:1-44.

Grow, J. A., and Sheridan, R. E., 1980. Deep structure and evolution of the continental margin off the Eastern United States. Geology of Continental Margins, Int. Geol. Congress, 26th, Paris, Coll. C3:11-19.

Hsü, K. J., and Bernoulli, D., 1978. Genesis of the Tethys and the Mediterranean. In Hsü, K. J., Montadert, L., et al., Init. Repts. $D S D P$, 42, Pt. 1: Washington (U.S. Govt. Printing Office), 943-949.

Jansa, L. F., Bujak, J. P., and Williams, G. L., 1980. Upper Triassic salt deposits of the Western North Atlantic. Can. J. Earth Sci., 17(5):547-599.

Jansa, L. F., Enos, P., Tucholke, B. E., Gradstein, F. M., and Sheridan, R. E., 1979. Mesozoic-Cenozoic sedimentary formations of the North American basin; western North Atlantic. In Talwani, M., Hay, W., and Ryan, W. B. F. (Eds.), Deep Drilling Results in the Atlantic Ocean: Continental Margins and Paleoenvironment. Am. Geophys. Union, Maurice Ewing Series, 3:1-57.

Jenkyns, H. C., 1980. Tethys, past and present. Proc. Geol. Assoc., 91:107-118.

Kelts, K., 1981. A comparison of some aspects of sedimentation and translational tectonics from the Gulf of California and the Mesozoic Tethys, Northern Penninic Margin. Eclogae Geol. Helv., 74 (2):317-338

Lagabrielle, Y., Lemoine, M., and Tricart, P., 1982. Les séries sédimentaires supra-ophiolitiques du Pelvas d'Abriès et de Rocca Bianca (Schistes lustrés du Queyras, Alpes occidentales françaises): temoins de l'activité tectonique de la croûte océanique téthysienne au Malm et au Crétacé inférieur. 9è Réun. Ann. Sci. Terre, Paris 1982, Soc. Géol. Fr. Paris, p. 351.

Lancelot, Y., 1980. Birth and evolution of the "Atlantic Tethys" (Central North Atlantic). Int. Geol. Congress. 26th, Paris 1980, Coll. 5:215-223.

Lancelot, Y., and Winterer, E. L., 1980. Evolution of the Moroccan oceanic basin and adjacent continental margin-a synthesis. In Lancelot, Y., Winterer, E. L., et al., Init. Repts. DSDP, 50: Washington (U.S. Govt. Printing Office), 801-821.

Laubscher, H., and Bernoulli, D., 1977. Mediterranean and Tethys. In Nairn, A. E. M., Kanes, W. H., and Stehli, F. G. (Eds.), The Oceans Basins and Margins (Vol. 4A): New York (Plenum), 1-28.

Lemoine, M., 1980. Serpentinites, gabbros and ophicalcites in the Piemont-Ligurian domain of the Western Alps: possible indicators of oceanic fracture zone and associated serpentinite protrusions in the Jurassic-Cretaceous Tethys. Arch. Sci. Genève, 33:103-115.

in press. Tectonique synsédimentaire mésozoique dans les Alpes Occidentales: naissance et évolution d'une marge continentale massive. In Lang, J. (Ed.), Livre Jubilaire G. Lucas: Mémoires géologiques de l'Université de Dijon, 7 (Diffusion B.R.G.M.).

Lemoine, M., Gidon, M., and Barfety, J. C., 1981. Les massifs cristallins externes des Alpes occidentales: d'anciens blocs basculés nés au Lias lors du rifting téthysien. C.R. Acad Sci. Paris, 292(II): 917-920.

Lowell, J. D., and Genik, G. J., 1972. Sea-floor spreading and structural evolution of the Southern Red Sea. Am. Assoc. Pet. Geol. Bull., 56:247-259.

Lowrie, W., 1980. A paleomagnetic overview of the Alpine system. Int. Geol. Congr. 26th, Paris, 1980., Coll. C5:316-330.

Manspeizer, W., Puffer, J. H., and Cousminer, H. L., 1978. Separation of Morocco and Eastern North America: a Triassic-Liassic stratigraphic record. Geol. Soc. Am. Bull., 89:901-920.

May, P. R., 1971. Pattern of Triassic-Jurassic diabase dykes around the North Atlantic in the context of pre-rift position on the continents. Geol. Soc. Am. Bull., 82:1285-1292.

Montadert, L., de Charpal, O., Roberts, D. G., Guennoc, P., and Sibuet, J.-C., 1979. Northeast Atlantic passive margins: rifting and subsidence processes. In Talwani, M., Hay, W., and Ryan, W. B. F., (Eds.), Deep Drilling Results in the Atlantic Ocean: Continental Margins and Paleoenvironment. Am. Geophys. Union, Maurice Ewing Series, 3:154-186.

Montadert, L., Roberts, D. G., Auffret, G. A., Bock, W., Dupeuble, P. A., Hailwood, E. A., Harrison, W., Kagami, H., Lumsden, D., Müller, C., Schnitker, D., Thompson, R. W., Thompson, T. L., and Timofeev, P. P., 1977. Rifting and subsidence on passive continental margins in the North East Atlantic. Nature, 268: 305-309.

Olivet, J. L., Bonnin, J., Beuzart, P., and Auzende, J. M., 1981. Cinématique de l'Atlantique Nord et Central. CNEXO-COB, Brest, France.

Pitman, W. C., and Talwani, M., 1972. Sea-floor spreading in the North Atlantic. Geol. Soc. Am. Bull., 83:619-646.

Roberts, D. G., and Caston, V. N. D., 1975. Petroleum potential of the deep Atlantic Ocean. Proc. 9th Petrol Congr.: Tokyo (Vol. 2), 281-298.

Scandone, P., 1975. Triassic seaways and the Jurassic Tethys Ocean in the Central Mediterranean area. Nature, 256(5513):117-119.

Scrutton, R. A., 1973. The age relationship of igneous activity and continental break-up. Geol. Mag., 110:227-234.

Sengor, A. M. C., 1979. Mid-Mesozoic closure of Permo-Triassic Tethys and its implications. Nature, 279(5714):590-593.

Sheridan, R. E., Gradstein, F. M., and Shipboard Scientific Party, 1982. Early history of the Atlantic Ocean and gas-hydrates on the Blake Outer Ridge-results of the Deep Sea Drilling Project Leg 76. Geol. Soc. Am. Bull., 93(9):876-885.

Smith, A. G., and Briden, J. C., 1977. Mesozoic and Cenozoic Paleocontinental Maps: Cambridge (Cambridge University Press).

Van Houten, F. B., 1977. Triassic-Liassic deposits of Morocco and Eastern North America: comparison. Am. Assoc. Pet. Geol. Bull., 61:79-99.

de Wever, P., and Caby, R., 1981. Datation de la base des Schistes Lustrés post-ophiolitiques par des radiolaires (Oxfordien supérieur-Kimméridgien inférieur) dans les Alpes Cottiennes (SaintVéran, France). C.R. Acad Sci. Paris, 292(II):467-472.

Winterer, E. L., and Bosellini, L., 1981. Subsidence and sedimentation on Jurassic passive continental margin, southern Alps, Italy. Am. Assoc. Pet. Geol. Bull., 65:394-421.

Zia, R., 1955. Calcari a Calpionelle della Toscana. Bol. Soc. Geol. Ital., 74:81-92.

Date of Initial Receipt: May 21, 1982 